\title{
Gaming as Civic Engagement in Salman Rushdie's Luka and the Fire of Life
}

\author{
Megan L. Musgrave
}

$\mathbf{S}$ alman Rushdie's 1990 novel Haroun and the Sea of Stories has received ample critical attention for diverse reasons. Not only was that book the first foray into children's literature by this noteworthy and notorious writer, but there was also a unique political context surrounding its publication. Rushdie's previous novel, The Satanic Verses (1988), had generated worldwide controversy due to what many Muslims felt was its disrespectful depiction of the Prophet Mohammed. In 1989 Iran's Supreme Leader, the Ayatollah Khomeini, issued a fatwa (a ruling based on religious law) condemning Rushdie to death for his blasphemy. Rushdie's 2012 memoir Joseph Anton provides new insights into his nine years spent in hiding in the wake of the fatwa and the personal and political motivations behind writing Haroun in the midst of chaos. Given Rushdie's troubled history as a writer; his provocative mapping of nation-building against identity politics in Midnight's Children (1981), The Moor's Last Sigh (1995), and Shalimar the Clown (2005); his iconoclasm in The Satanic Verses; and his strong argument against censorship in Haroun and the Sea of Stories, one might expect Rushdie's second novel for children, Luka and the Fire of Life (2010), to be a similarly political and provocative text.

Yet Luka has provoked little critical response in comparison with Rushdie's other work. Perhaps this is because more than two decades have passed since the onset of "the Rushdie affair" and the context of this novel's publication is not as risky as that of its predecessor — - though the fatwa was never revoked and Rushdie's recent public support of the French satirical magazine Charlie Hebdo (Lynch) has cemented his long-standing position on Al Qaeda's Most Wanted list (Bennet). Perhaps the lack of scholarly interest in Luka is because at first glance, it appears to be little more than a retelling of Haroun: it is explicitly dedicated to and written for one of Rushdie's own children ${ }^{2}$; it centers

Megan L. Musgrave is an assistant professor of English at Indiana University-Purdue University at Indianapolis, where she teaches children's literature, young adult literature, and Native American literature. She is currently completing a book manuscript entitled Digital Citizenship in Twenty-First Century Young Adult Literature: Imaginary Activism. 
on the legendary storyteller Rashid Khalifa and prioritizes a central father-son relationship; and its plot is set in motion by the unexpected power of the young protagonist's speech-act and resolved when he overcomes the challenges of a journey into a magical world created by his father's storytelling. Or perhaps it is because Haroun makes a powerful argument against the censorship that its author experienced in his own life, whereas Luka at first appears somewhat less political, less urgent.

However, on close reading, Luka and the Fire of Life reveals its own politics: not because it presents a powerful allegorical justification for the importance of freedom of speech (though it does this, too), but because of how it engages twenty-first-century cultural and generational concerns about the role of technology in daily life. Whereas the story moon Kahani in Haroun is an explicit nod to $\mathrm{Oz}$ and the other Wonderlands that influenced Rushdie as a writer, the magical world in Luka is structured like a video game. Specifically, the book's narrative structure borrows from Super Mario Brothers, Sonic the Hedgehog, and other games that Rushdie played to pass the time during his exile (Rushdie, Joseph Anton 229) and still plays today as a means of bonding with his sons (Rushdie, "Video Games"; Medley). Rushdie uses gaming to express anxiety over his own aging process by choosing a medium associated with youth culture to structure his narrative; simultaneously, he engages an ongoing cultural debate concerning the potentially detrimental influence of gaming on young people. Rather than reinforcing the barrier between youth and the older generation, Luka and the Fire of Life argues that "old" storytelling modes must always be revived in new ways to remain relevant to new generations for whom personal technology is becoming less a mode of entertainment and more a necessary tool for functioning in the world. With the story of Luka and Rashid Khalifa, Rushdie argues that video games have the potential not only to bridge the generation gap, but also to develop problem-solving skills and civic engagement among children.

By virtue of Luka's existence as a ludic (game- or play-oriented) text, Rushdie has set foot on the playing field of contemporary game studies. Game studies began to develop into a legitimate field of academic study in the mid-1990s, although, as Ian Bogost explains in Persuasive Games, the field still struggles to attain legitimacy in academia. In part, he claims this is because gaming as a medium has been associated with children's culture. But while children's literature finally has come to be seen as a viable field of academic study, "Videogames are [still] considered inconsequential because they are perceived to serve no cultural or social function save distraction at best, moral baseness at worst" (Bogost viii). As Bogost implies, there are two persistent major criticisms of gaming: first, there is a pervasive concern that time spent gaming or using personal technology for social media is detrimental to children (Jenkins, Challenges 14). Second, researchers have long suspected a positive correlation between violent games and violent behavior, though as yet no such correlation has been made (Ferguson and Kilburn 762; Kahne et al. 2; Block 30). In their 
2009 report The Civic Potential of Video Games, Joseph Kahne, Ellen Middaugh, and Chris Evans acknowledge that "To date, the main areas of research have considered how video games relate to children's aggression and to academic learning. However, digital media scholars now suggest that other social outcomes also deserve attention. For example, as games become more social, some suggest they can be important spheres in which to foster civic development" (2-3). Cynthia Selfe, Anne F. Mareck, and Josh Gardiner echo this imperative, suggesting that "perhaps in our well-intentioned concern for our youth, we have been inclined to overlook or dismiss the positive, exciting, socially transformative developments in computer gaming-or the skillful, tactical agency that young people, themselves, can enact" (33).

In response to such concerns, a surge of scholarship in game studies in the twenty-first century is exploring the positive social and educational potential for skill sets developed through gaming. This exploration has been spearheaded by the groundbreaking work of James Paul Gee, whose What Video Games Have to Teach Us About Literacy and Learning has established vital new connections between the fields of game studies and of educational theory and practice. Bogost argues that the positive potential of using game theory to reshape educational practices may overshadow the negative connotation gaming often carries for those outside the culture: "In addition to becoming instrumental tools for institutional goals, videogames can also disrupt and change fundamental attitudes and beliefs about the world, leading to potentially significant long-term social change" (ix). These "socially transformative" possibilities constitute the aspect of gaming that has captured Rushdie's imagination in Luka and the Fire of Life.

Yet cultural anxiety concerning video games and their impact on youth persists, and as if in response, a surge of increasingly diverse and nuanced fictional adaptations of gaming and its culture is a prominent feature of twenty-first-century young adult literature. Luka is one example of a growing subgenre shaped by texts such as The Long Walk (Stephen King, 1979), Ender's Game (Orson Scott Card, 1985), Battle Royale (Koushun Takami, 1999), the Avatar Chronicles trilogy (Conor Kostick, 2004-11), the Hunger Games trilogy (Suzanne Collins, 2008-10), Ready Player One (Ernest Cline, 2011), and Guy in Real Life (Steve Brezenoff, 2014). Such texts reveal the philosophically interesting consequences of employing high-stakes games to explore the struggles of adolescent characters. ${ }^{3}$ Cory Doctorow is the most prolific contributor to this fictional niche; he uses the connections between gaming and activism to promote real-world civic engagement in Down and Out in the Magic Kingdom (2003), Little Brother (2008), For the Win (2010), Homeland (2013), and In Real Life (2014). In various ways, all of these texts represent gaming and digital media as aspects of what Henry Jenkins defines as a "participatory culture," one that offers "opportunities for learning, creative expression, civic engagement, political empowerment, and economic advancement" (Challenges 9). Authors experimenting in this subgenre use fiction to imagine the different ways in which gaming strategies might prepare individuals to become active 
and engaged citizens and leaders. Importantly, in the majority of these texts, issues of individual agency and empowerment eclipse considerations of intergenerational cooperation in the digital age.

Indeed, as exemplified by the protest group in Little Brother that insists, “DON'T TRUST ANYONE OVER 25" (173) - an echo of the 1960s counterculture warning "Don't trust anyone over thirty" - the vast majority of ludic fiction emphasizes the generational divide and exploits it for dramatic tension rather than exploring the possibility that gaming might actually bring parents and children together. Science fiction and dystopian texts such as Ender's Game, The Hunger Games, Ready Player One, and David Thorpe's Hybrids pit child protagonists against adult militaristic or corporate power. More realistic texts such as Guy in Real Life, Janet Tashjian's The Gospel According to Larry, and In Real Life present parents and other adults as obstacles to young people's efforts to grow and build communities via gaming and other digital activities. One significant exception is Kostick's Epic, in which protagonist Eric struggles to beat the game that has been created to control society, only to discover that one of the game's most skilled and notorious players is his own father. Rushdie similarly explores intergenerational gaming in $L u k a$, though the role of gaming in maintaining and preserving parent-child relationships is more central here. ${ }^{4}$

Like many game critics, Rushdie expresses certain concerns about the potential influence of gaming upon our humanity: "We may actually have a story instinct and so there is a legitimate concern about a new form which may erode our attachment to the story. What will that do to us as human beings?" "Video Games"). However, in the end Rushdie is more interested in the potential of video games as a new platform for storytelling than he is concerned about their ability to "erode our attachment to story": "I mean I don't even pretend to understand what is going on really, but one of the things that is interesting about it to me is the much looser structure of the game and the much greater agency that the player has to choose how he will explore and inhabit the world that is provided for you" ("Video Games"). Through Luka, Rushdie considers the creative potential of games as a new mode of storytelling and argues that experience with video games can produce better thinkers, storytellers, problem solvers, and citizens. Rushdie, so well known for his consistent emphasis on the transformative power of storytelling, suggests that adapting the structure of a video game allows him to use children's fiction as a space for experimentation with narrative:

There is [sic] all kinds of excursions and digressions that you can choose to go on and find many stories to participate in instead of the big story, the macro story. I think that really interests me as a storyteller because I've always thought that one of the things that the Internet and the gaming world permits as a narrative technique is to not tell the story from beginning to end - to tell stories sideways, to give alternative possibilities that the reader can, in a way, choose between. ... But it seems to me that in some ways the Internet is the garden of forking paths where you can have myriad variant possibilities offered and at the same 
level of authority, if you like. So I mean I think that's one of the ways in which storytelling could move. And these games, these more free-form games in which the player can make choices about what the game is going to be, become a kind of gaming equivalent of that narrative possibility. ("Video Games")

Rushdie's argument contradicts the common concern that video games limit children's intellectual development and storytelling skills by "supplanting the world of story" (Medley); in fact, he implies, gaming capitalizes on the player's innate desire to create stories. Rushdie's interest in video games reflects changing critical views on their value as emerging platforms for the most ancient art form, storytelling. Game theorist Grant Tavinor argues that games provide opportunities for an exploration of identity similar to those of "traditional" fictional texts: "So that the player can adopt a role in the fictional world of a videogame, many videogames represent the player as a character within that world.... Videogames expand on this representation of a perceiving self within the fictional world, also allowing the subject to act" (70; emphasis in original). Considered in this light, video games emerge as a form of narrative that does what all narratives do: they satisfy Horace's argument that literature should "delight and instruct" by encouraging reader-participants to examine their value systems and develop self-awareness. As the following analysis will show, Luka and the Fire of Life supports this stance, which complicates the common assumption that video games exist to serve only one function, to delight. Furthermore, because Luka reflects the fact that technology plays a prevalent role in contemporary life, Rushdie suggests that gaming can help the younger generation role-play civic activities that may translate into real-world activism.

Luka and the Fire of Life, then, dramatizes two key preoccupations of Rushdie himself: first, presumably because the author himself is twenty years older and has survived a ten-year exile and several assassination attempts since the publication of Haroun, ${ }^{5}$ the older generation's preoccupation with mortality and the preciousness of time are central. Second, experimentation with using technology to keep storytelling alive articulates his concern for the future of storytelling in an increasingly technological world. In line with these concerns, the title character of Luka is a "miracle child" whose birth confirms to his aging parents that their story is not ending yet. Rashid and Soraya Khalifa are fifty and forty-one years old, respectively, when Luka is born: "His name is Luka," Soraya says, "and the meaning of the wonder [of his birth] is that we appear to have brought into the world a fellow who can turn back Time itself, make it flow the wrong way, and make us young again" (10). While it is not as remarkable for Soraya to give birth to a child at age forty-one as it is for the biblical Sarah to give birth to Isaac at age ninety, Rushdie certainly echoes the Abrahamic myth here (Genesis 17-21), and in particular echoes that story's central idea that parenthood is the route to immortality. ${ }^{6}$

Having established the "miracle" of Luka's birth to parents who view themselves as aging, Rushdie simultaneously introduces the themes of activism and 
mortality via a crisis that threatens to end Rashid Khalifa's life. When the Great Rings of Fire Circus comes to town, Rashid refuses to let Luka go due to ethical objections; the circus leader, "Captain Aag, a.k.a. Grandmaster Flame” (Luka 4), has a horrible reputation for exploiting and abusing the animals in his care. In a flash of righteous indignation, Luka confronts the Grandmaster and curses him: "May your animals stop obeying your commands and your rings of fire eat up your stupid tent" (6). Like his brother Haroun before him, Luka does not understand the power of his own speech-act. ${ }^{7}$ Shortly after he issues this curse, Luka and his family are astonished to discover that it has had the desired effect: the disenfranchised animals have "rebelled against their master in an unprecedented act of defiance," and flames consume the Big Top of the circus (6). In short, "Luka's curse had worked" (7), and the child's innate impulse to act on his social conscience and protest injustice sparks his unexpectedly powerful speech-act. Although the explicit connection to gaming has not yet been made, already Luka has established his ability to displace a power structure with the use of his wit and words, tools essential to his success as he discovers the game at the core of the World of Magic.

Unfortunately, Luka does not realize that Grandmaster Flame's powers transcend the real world of circuses and animal rights. When Luka's curse shuts down his livelihood, the Grandmaster responds by cursing Luka's father into a coma. Shortly thereafter, Luka meets Nobodaddy, a ghostly doppelgänger of his father whose presence becomes more and more tangible as Rashid's life slowly slips away. ${ }^{8}$ Luka learns from Nobodaddy that the only way to save his father is to journey into the World of Magic and take on a Promethean quest to retrieve the Fire of Life that will revive him. In short, the child's activist impulse to free the circus animals forces him to journey into a new and more complex world in order to restore order to his own life. As Luka discovers, the World of Magic is the creation of Rashid Khalifa and his marvelous imagination, and it is this world that Luka must struggle to navigate, by decoding its rules.

Fortunately, Luka is fluent in a language that helps him with this project: that is, the language of technology — and, specifically, of video games. After all,

Like everyone he knew, he had joined imaginary communities in cyberspace, electro-clubs in which he adopted the identity of, for example, an Intergalactic Penguin named after a member of the Beatles, or, later, a completely invented flying being whose height, hair color, and even sex were his to choose and alter as he pleased. Like everyone he knew, Luka possessed a wide assortment of pocket-sized alternate-reality boxes, and spent much of his spare time leaving his own world to enter the rich, colorful, musical, challenging universes inside these boxes, universes in which death was temporary (until you made too many mistakes and it became permanent) and a life was a thing you could win, or save up for, or just be miraculously granted because you happened to bump your head into the right brick, or eat the right mushroom, or pass through the right magic waterfall, and you could store up as many lives as your skill and good fortune could get you. (14) 
The term "pocket-sized alternate-reality boxes" refers to any number of handheld video game-delivery devices, from game consoles to smartphones to tablets and laptops, all now fixtures in middle- to upper-class adolescents' lives (Jenkins, Challenges 3). Luka implies that the worlds offered by these devices are more dynamic, more exciting, more "colorful, musical, challenging" than the real world, echoing adult fears that virtual worlds and their delights are more enticing for kids than the real world and its responsibilities. Indeed, disagreement between Luka's parents concerning the value of video games stands in for real-world debates over this issue. Rashid, who tries, "with comically little skill, to join him on his adventures," insists that gaming is developing Luka's "hand-eye coordination, and he is solving problems, too, answering riddles, surmounting obstacles, rising through levels of difficulty to acquire extraordinary skills" (Rushdie, Luka 15). But Soraya, representing the skeptical position, argues, "They are useless skills... In the real world, there are no levels, only difficulties. If he makes a careless mistake in the game he gets another chance. If he makes a careless mistake in a chemistry test he gets a minus mark. Life is tougher than video games. This is what he needs to know, and so, by the way, do you" (15). The discursive position that Soraya represents—resistance to seeing potential good results from gaming activities - has fueled the current second wave of responses from game studies scholars. Together, the work of Jenkins, Bogost, Gee, Jane McGonigal, and other critics is building a strong case against the antigaming position that Soraya articulates; instead, they suggest, learning may be enhanced, and life may actually be made easier, by using games and gaming strategies across a wider variety of real-world contexts.

One sensibility that gaming has helped Luka to cultivate, and that will prove essential to the success of his quest, is the casual belief that in games, "death [is] temporary" (14). The gamer's understanding of the temporary nature of death in game-world both contradicts the very real, waning mortality of his father and helps Luka to overcome fear as he faces the perils of his adventure. Egged on by the appearance of Nobodaddy, whose presence represents Rashid's looming death, the left-handed Luka steps onto the Left-Hand Path and into the World of Magic to discover a landscape structured exactly like the video games he and his father are so fond of playing. The trials he must survive en route to capturing the Fire of Life are structured like the "levels" in classic adventure games such as Super Mario Brothers; each time he accomplishes a task or defeats an enemy, he must find the golden button that allows him to save his game so that he is not sent back to the beginning whenever he "dies." A life counter and a level counter appear in the corner of his visual field, and he immediately understands that he must collect additional lives as he makes his way through the World of Magic so that his cache of lives will not be empty when he meets his greatest challenges. In the adventure game format, players rely on hand-eye coordination, puzzle-solving skills, and learning the tricks of the game (hidden weapons, hidden caches of extra lives, and so on) in order to advance. In this way, Luka employs the ludic mechanics that Astrid Ensslin 
identifies as central to "ludic-literary works that borrow from computer game technologies and structures such elements as rule-driven action, performance measurement, credit counts, winning and losing mechanisms, rewards, tasks, and challenges" (12). While Ensslin discusses ludic mechanics as a central feature of much contemporary digital literature, such structures are certainly important to all texts that employ game structures, and Luka acknowledges this importance explicitly. He thus demonstrates what Bogost defines as procedural literacy, "playing a videogame or using [a] procedural system with an eye toward identifying and interpreting the rules that drive that system" (64). Because the World of Magic is structured by rules with which Luka is familiar, he easily adapts to the new environment and understands that it will constantly challenge his problem-solving skills.

However, Luka's potential delight in the playful aspects of his adventure is eclipsed by the deadly seriousness of Rashid's predicament. Luka quickly realizes that he is willing and able to sacrifice his own "life" many times over in order to pursue his greater objective of recovering his father's life. In other words, true to the story's epic structure, the hero gains self-awareness and clarity about his value system by pursuing his quest. ${ }^{9}$ Luka experiences his own death each time he meets a foe who manages to "kill" him, often repeatedly, until he solves the problem presented by the obstacle. The first time, he dies at the hands of the Old Man of the River, an incarnation of Charon, the ferryman of Greek mythology. The river in this instance is the River of Time that flows through the World of Magic:

In front of him flowed the Present, brilliant, mesmerizing, and he was so busy staring at it that he didn't see the Old Man of the River until the long-bearded fellow came right up in front of him holding a Terminator, an enormous sciencefiction-type blaster, and shot him right in the face.

BLLLAAARRRTT!

It was interesting, Luka thought as he flew apart into a million shiny fragments, that he could still think. He hadn't thought that thinking would be a thing you would be able to do when you had just been disintegrated by a giant sciencefiction-type blaster. (Rushdie, Luka 48-49)

As in Haroun, where complex concepts are repeatedly written off as P2C2E's or "Processes Too Complicated To Explain," here Rushdie humorously resists falling into jargon and instead uses clunky descriptors such as "giant sciencefiction-type blaster" to reflect the child protagonist's first impression of this assault. The fact that Luka experiences his own death immediately upon entering this world is typical of game design, according to Jenkins: "The heavy-handed exposition that opens many games serves a useful function in orienting spectators to the core premises so that they are less likely to make stupid and costly errors as they first enter into the game world" "Game Design" 126). Because he is functioning within the familiar framework of a video game, Luka responds rationally to his own disintegration. His ease in adjusting to his many "deaths" suggests that the twenty-first-century child's 
understanding of mortality is shaped by his exposure from a young age to "imaginary communities in cyberspace" (Rushdie, Luka 14), enabled by the Internet and fostered by interactive, Web-based video games and social networks. Luka, then, has a sense of identity that encourages performativity and malleability across a variety of contexts. At this stage, his choices demonstrate his high level of local agency in the game, "when the player's actions cause immediate, context-specific, meaningful reactions from the system" (Mateas and Stern 203-04). In this case, the "meaningful reaction" that he provokes is the disintegration of the antagonist; he is goaded by the Old Man of the River into a battle of wits, and Luka defeats him after a clever exchange of riddles. Recognizing that the World of Magic and all its inhabitants are constructions of his father's mind, Luka remembers that his father never could remember the answer to the riddle of the Sphinx. If Rashid could not know the answer, then the Old Man of Rashid's imagination cannot know the answer, either, and thus he is stumped-and then disintegrated-when Luka recites the ancient riddle. Thus, Luka constantly negotiates between the two structures his father has used to shape this world: the rules of the adventure game format and the mythological traditions of countless cultures.

Learning from this first battle of wits and immediately recognizing that he will die many times as he solves the problem presented by each obstacle, Luka begins to collect additional lives wherever he goes, finding that "Lives were everywhere, in everything, disguised as stones, vegetables, bushes, insects, flowers, or abandoned candy bars or bottles of pop; a rabbit scurrying in front of you could be a life and so might be a feather blowing in the breeze right in front of your nose. Easily found, easily gathered, lives were the small change of this world, and if you lost a few, it didn't matter; there were always more" (Luka 49-50). Ironically, while Luka's training in video game culture prepares him to take a cavalier attitude toward his own mortality, he is in this World of Magic to prevent the very real death of his father, who has not a single life to spare in the game. Luka is constantly reminded of Rashid's slow deterioration by the increasingly opaque presence of Nobodaddy: "He understood what the see-through Rashid was telling him. As his father faded away, the phantom Rashid would grow stronger, and in the end there would only be this Nobodaddy and no father at all" (28). In Nobodaddy, Rushdie has created a uniquely horrifying villain. He is a comforting presence to the boy because he looks and sounds like Rashid, and thus he provides the illusion of protection for Luka as he travels through the World of Magic and endures its trials. However, Nobodaddy's increasingly material presence is yet another example of the text's ludic mechanics, a visual marker of Rashid's decline. Therefore, as he learns to navigate the game of the magical world, Luka must consciously resist the temptation to rely on Nobodaddy and must instead act on his rational knowledge that the specter is a parasite.

Luka's anxiety is well founded, for, like his brother's before him, his quest has both local and global consequences; he must revive the source of all stories 
(his father) in order to preserve both his family and the tradition of storytelling that Rashid singlehandedly perpetuates, according to the rules of this narrative. Rather than representing a threat to freedom of speech as it so explicitly does in Haroun, here the illness of Rashid Khalifa has more personal, physiological implications. Rashid is not debilitated here by an affront to his profession as storyteller or to his manhood, ${ }^{10}$ but rather by the onset of old age, a source of anxiety signified by the Grandmaster's curse upon him. Horrified to see his father "in the grip of the Big Sleep," Luka suddenly confronts the most difficult reality for any child to process, namely the death of a parent: "It felt as if a thing that had been impossible had become possible, a thing that had been unthinkable had become thinkable, and Luka did not want to give that terrifying thing a name" (20). Luka's thoughts here echo those of Haroun, for whom the Unthinkable Thing was his father's sudden inability to tell stories (Rushdie, Haroun 22). In each case, the Unthinkable Thing forces the child to face not only his parent's mortality, but also his own mortality by proxy. This theme is dramatized perhaps most profoundly by J. M. Barrie's Captain Hook, a character whose anxiety over his own mortality (in contrast to Peter Pan's heartless immortality) manifests in the stalking crocodile. What Hook fears most is not the crocodile herself but the ticking clock inside her, and the inevitable winding down of his own life along with the clock. In Luka's case, the connection between the World of Magic and the storyteller who created it is likewise essential, and as Rashid's life fades away, the world gradually begins to crumble around Luka.

As Luka progresses through the levels of the game, acquiring friends and a magic carpet that help him in his pursuit of the Fire of Life, he discovers that this world is populated by virtually all of the deities ever worshipped by human cultures. Rashid's magical imagination has preserved them even after modern people have ceased to worship them. In this cross-cultural gathering of gods, Rushdie includes a variety of comic juxtapositions. The female beauty goddesses, for example, pass eternity by having intermythic beauty contests, while the male deities compete through feats of strength. Rushdie relies upon the legendarily ridiculous shenanigans of such deities to great comic effect here. On the day of Luka's visit, the Greek goddess Aphrodite defeats a variety of beauty goddesses, ranging from the Japanese rasetsu Kishimojin to the Babylonian Ishtar, the Roman Venus, the Sumerian moon goddess Mylitta and the Aztec vampire queen Xochiquetzal (Luka 136-37). The depiction of gender roles can be interpreted as satirical and as demeaning to women and men alike, and it reflects the long history of sexual inequality across a variety of human societies. Rushdie's acknowledgment of sexual inequality in his game world also serves as a reminder that such inequality is still a problem in video game culture today (cf. Cassell and Jenkins; Sydell).

That said, if the beauty goddesses and Luka's mother Soraya-whose role in this novel is far more tangential and shallow than her role in Haroun-were the only female characters in this text, it would be easy to dismiss Rushdie as 
simply perpetuating the negative video game stereotypes that Anita Sarkeesian claims "help to normalize extremely toxic, patronizing and paternalistic attitudes about women." There is, however, a single female character in Luka who complicates Rushdie's otherwise simplistic characterizations of women. Soraya, the "Fairy Queen of the Otters" (82), the "Insultana of Ott," and the owner of King Solomon's flying carpet, which safely transports Luka through the World of Magic (84), combats negative stereotypes and presents a complex example of a woman who is more than a rhetorical stand-in or an object of beauty. Unattached to any mythological or cultural tradition, Soraya is an assertive, witty ally whose characterization as both a maternal figure (she is named after Luka's own mother) and a potential romantic partner (Luka has a huge crush on her) has obvious psychoanalytic implications but also suggests Rushdie's wish for more complex, developed female characters in video games. A more developed character than Haroun's unfortunately named friend Blabbermouth, Soraya serves as a sassy, opinionated partner in crime for the male protagonist. Like Luka, she is an adept strategist in the game; he wins her loyalty by suggesting that they deploy itching-powder bombs to defeat her mortal enemies, the censoring and politically correct Rats of the Respectorate of I. She likewise wins Luka's loyalty by agreeing to pilot him and his growing troop of allies on her magic carpet through the World of Magic and toward the Fire of Life at its heart. Soraya, who is outspoken, always armed with a quill of witty insults, and deeply opposed to rules and political correctness, is delighted to join with Luka on his criminal quest: "To steal the Fire of Life, which has never been done in the whole history of the Magical World! Why, that would be the most deliciously Disrespectful deed in All of Time!" (91). Soraya is a liminal figure for Luka; she is both a strategic partner and a source of comfort who acts as a counterpoint to the increasingly threatening Nobodaddy. She also serves an essential function by helping Luka navigate the game, delivering him to the Heart of Magic, and eventually safely bringing him to the border of the real world again. As such, this single female character combats the limited characterizations of other females in the text and serves as an olive branch to feminist critiques of a text that is still dominated by a classically male quest narrative.

When Luka reaches the Heart of Magic and thus his greatest moment of crisis and possible failure, he finally overcomes the game's linear structure by exercising global agency in the game, the point at which "the global shape of the experience is shaped by player action" (Mateas and Stern 205). In this way, Rushdie provides an unexpected answer to game theorist Eric Zimmerman's question, "How can we capitalize on the unique qualities of games in order to create new kinds of game stories? What if dynamic play procedures were used as the very building blocks of storytelling? ... Mischief is a form of play. What would a game be like that encouraged players to break existing rules in order to form new ones?" (163; emphasis in original). This seems to be what Rushdie is attempting in $L u k a$; he is using the vocabulary of a game, and the idea of breaking the rules of that game, to imagine such mischief-making as the basis 
for activism and community-building. As Luka approaches the heart of the World of Magic where all of the deities, including the great Prometheus himself, guard the Fire of Life, he must make mischief by disrupting their worldview and persuading them that the only reason they still "exist" is that his father has continued to tell stories about them. As Luka insists to the gathered army of deities who stand between him and saving his father's life, "Everything here will vanish, too; I don't know what will become of you all exactly but, at the very least, you won't have this comfortable World to live in anymore. [...] And in the worst-case scenario you will disappear completely—poof!—as if you had never been, because let's be frank, how many people other than Rashid Khalifa are really bothering to keep your story going nowadays?" (Luka 183). This is a recipe for Rushdie's own endlessly layered literary allusiveness; if Rashid survives, the storytelling tradition lives on-and this tradition is the immortals' only hope for immortality.

Luka's quest therefore anticipates and recreates his storyteller father's function of preserving imagination. In this sense, Rushdie echoes T. S. Eliot's argument in "Tradition and the Individual Talent," in which Eliot contends that all writers must simultaneously create new stories and incorporate the literary tradition(s) that brought them into this time and place. A writer who rarely gets through a sentence without alluding to another text or film, Rushdie captures the essence of Eliot's argument; he relies as heavily upon Greco-Roman, Egyptian, Native American, and other mythological traditions as he does upon Indian mythology from his own cultural heritage and upon twentieth- and twenty-first-century music, films, and print texts. He does not privilege "high" culture over "low" or popular culture, but uses intertextuality while appropriating ancient story cycles to new ends for contemporary readers. ${ }^{11}$ The same is true of video games; just as game designers borrow from a huge variety of mythological traditions when they create games, Rushdie does not shun games as low culture. They are as ripe with possibility as any other narrative form.

In this case, Luka has the epiphany that the mythological celebrities inhabiting the World of Magic are interested in self-preservation, and he uses this understanding to persuade the gods and goddesses to help him beat the game and capture the Fire of Life:

Wake up and smell the coffee, old-timers! You're extinct! You're deceased! As gods and wonderful creatures, you have ceased to be! ... You aren't really the gods of anywhere or anyone anymore. You no longer have the power of life and death and salvation and damnation. [...] Listen to me: it's only through Stories that you can get out into the Real World and have some sort of power again. When your story is well told, people believe in you; not in the way they used to believe, not in a worshiping way, but in the way people believe in stories-happily, excitedly, and wishing they wouldn't end. You want Immortality? It's only my father, and people like him, who can give it to you now. My father can make people forget that they forgot all about you, and start adoring you all over again and being interested in what you've been getting up to and wishing that you wouldn't end. And you're 
trying to stop me? You should be begging me to finish the work I came here to do. [...] Who am I? I'm Luka Khalifa. I'm the only chance you've got. (183-84)

In the course of arguing in favor of his father's life, Luka also validates the interconnections among belief systems, their mythologies, and immortality. The gods remain immortal only when their stories are "well told" so that people continue to believe in them. In making this case, Luka also affirms his own identity, purpose, and power as an advocate on behalf of his father and the storytelling traditions he preserves. Thus, in the radical act of facing down the world's most powerful deities, Luka suddenly empowers himself as a mere human whose belief in them is the key to their immortality. Once again, his unexpectedly powerful speech-act changes their communal narrative just as it changes the rules of the game itself.

Having persuaded the gods to help him in the interest of their own selfpreservation rather than standing in the way of his progress, Luka must face the final opponent in this game: the gamemakers themselves. The Aalim, or "Learned Ones," control the River of Time that constitutes the past, present, and future. ${ }^{12}$ When Luka locates the Aalim at the center of the game and attempts to persuade them to let him leave the World of Magic with the Fire of Life- thus releasing the core secret of that world into the real world and also buying more precious years for his father-they respond implacably:

Compassion is not our affair... The ages go by heartlessly whether people wish them to do so or not. All things must pass. Only Time itself endures. If this World ends, another will continue. Happiness, friendship, love, suffering, pain are fleeting illusions, like shadows on a wall. The seconds march forward into minutes, the minutes into days, the days into years, unfeelingly. There is no "care." Only this knowledge is Wisdom. This wisdom alone is Knowledge. (201; emphasis in original).

The Aalim's nihilistic philosophy horrifies Luka, whose entire mission is fueled by compassion for his dying father, and whose life is ruled by the emotions that the Aalim compare to "shadows on a wall." ${ }^{13}$ In other words, the knowledge that human experience is fleeting has no value for Luka; as a gamer, he has many lives, but as a son, he finds the value of his father's single human life paramount. Just as he cursed Grandmaster Flame, Luka curses the Aalim-except that this time, he is fully aware of his power. Just as Haroun denounced the Ayatollah figure of Khattam Shud for attempting to control all the world's stories, Luka denounces the Aalim for attempting to control time. Rather than taking a dispassionate, nihilistic approach to the past, present, and future, Luka demands "The Overthrow of the Dictatorship of the Aalim by the Inhabitants of the Heart of the Magical World, and its Replacement by a More Sensible Relationship with Time, Allowing for Dream-time, Lateness, Vagueness, Delays, Reluctances, and the Widespread Dislike of Growing Old" (204; emphasis in original). Now aware of his own power as one whose words become reality, Luka echoes the timetwisting game Prince of Persia: The Sands of Time and makes mischief with the 
highly structured approach to the game of Time just as he defies the prescribed structure of the adventure game. His words frame a new approach to Time, one in which a "more sensible relationship with Time" means that the individual need not be controlled by the highly structured, anxiety-laden thinking that gives Time its power. Notably, his reframing of Time echoes his father's own anxiety about growing old. When Luka defies the Aalim's monopoly over the interconnected institutions of Time and Knowledge, the Aalim become irrelevant. In their place, Luka's words manifest a new reality shaped by a playful, lackadaisical approach to Time; he restores a more childlike view on the notion of mortality, one that borrows from a gamer's understanding of an endless well of lives and makes the passage of Time seem much more whimsical, less heartless and inevitable.

Luka's powerful speech-act diminishes the Aalim to "shadows on a wall," and they are rendered powerless to interfere with his quest. Just as the World of Magic threatens to crumble away completely, its reinvigorated deities help him finally to return to his father. Queen Soraya remarks on the revolutionary power of Luka's words to unite the previously divided, competitive rabble of gods: "And you see that bunch of flying Wind-Lions, the Fong-shih-ye from the Kinmen Archipelago of Taiwan? The Chinese usually refuse to speak to them, or even to accept that they exist—but here they are, working together! It's really amazing how everyone has united behind you!" (207). Luka's revolutionary speeches transform the gods' view of themselves; they leave behind their cultural differences to unite for self-preservation. Conveniently, this newly united community of gods assures Luka's safe arrival home with the Fire of Life, the revival of his father, and the banishment of Nobodaddy into oblivion. As Rashid awakes from his sleep and Luka breathlessly relates his adventure to his father, his mother is quickly lost in the torrent of words pouring forth from storyteller to storyteller: "I don't know what you two are talking about,' said Soraya Khalifa contentedly, 'but it's good to hear the old rubbish being spoken in this house again"” (213). "The old rubbish," those ancient stories told and recycled again and again over time, is the foundation of storytelling, and thus of human history, education, and entertainment.

Using the straightforward structure of the classic adventure game as a metaphor for conformity, Luka and the Fire of Life encourages readers to consider gaming as a means of enhancing problem-solving skills and reenvisioning the great controlling structures of life, such as Time. Luka thereby applies a skill set developed via his chosen form of entertainment to exert creative thinking, agency, and power in a way that guarantees not entertainment but survival—of his father's life and storytelling practice, and also of the innumerable deities kept alive and relevant by that practice. Luka's ability to unite the rabble of deities supports Kahne, Middaugh, and Evans's argument that games are capable of "socializ[ing] young people to value and pursue social ties" and may also expose players to "organizational norms and relevant political and social skills that enable them to maintain these ties.... To the extent that games are 
played with others or integrate youth into vibrant communities where healthy group norms are practiced and where teenagers' social networks can develop, games might well develop social capital" (21). In this case the "social capital" in question helps the inhabitants of the World of Magic learn to value their communal power over their differences, and helps Luka build a bridge between the magical and the real that saves his father's life.

Rushdie's pastiche of mythological and storytelling traditions and practices, including the contemporary practice of gaming as a narrative structure, allows him to explore the interplay of these many traditions in contemporary culture. Here he blends his own investment in storytelling as a vital cultural practice with anxiety over his own vitality and mortality; accessing the youth culture and its preferred modes of storytelling provides Rushdie/Rashid with a new means of attaining immortality. One can live on through the oral storytelling and mythological tradition, or through one's novels, but one can also use technology-ironically, a mode of communication that is always obsolete by the time it reaches its audience- to contemplate new modes of attaining immortality. Gaming is a mode of discourse that can present new modes of storytelling here in the twenty-first century. Rushdie's message is that technology can indeed both delight and instruct. In this way, he anticipates a central argument of Jane McGonigal's influential book Reality Is Broken: Why Games Make Us Better and How They Can Change the World. McGonigal claims that "there's good reason to believe that the more we learn to enjoy serving epic causes in game worlds, the more we may find ourselves contributing to epic efforts in the real world" (114). Rushdie provides transhistorical closure to her argument by dramatizing the debt that contemporary technology owes to ancient tradition. Rather than viewing technology as a means of mindless entertainment, we should recognize that it provides an opportunity to be creative and to challenge outmoded structures or overly structured ways of thinking about time and relationships. Luka's ability to defeat the game suggests the individual's potential not to be merely a cog in the system, but to reinvent the system itself.

As this discussion shows, Luka and the Fire of Life is less an argument for freedom of speech than is Haroun and the Sea of Stories, and more an endorsement of speech as a vital aspect of an evolving storytelling and political tradition. Rashid's mortality metaphorically represents the threat of losing sight of stories altogether in light of the changes wrought by digital technology, whether imposed by a fatwa or by the more mundane but ever present "pocket-sized reality boxes." However, Luka's ability to use his own knowledge of personal technology to sharpen his problem-solving skills represents the hope that our love of media and technology can inspire young people to integrate entertainment and citizenship-building activities. Luka takes up Haroun's argument in favor of imaginative freedom with enthusiasm, and with a twenty-first-century understanding of the value and power of rhetoric as the basis for political activism. 


\section{Notes}

1. In short, Haroun's potential as a protest novel was limited by its marketing as a book for children. The cultural dismissal of children's literature and critical blindness to its politics prevented a new wave of agitation against Rushdie, but also prevented Haroun from being broadly received as the radical text that it is.

2. Rushdie's anecdotes about his son Zafar's role as the first "editor" of Haroun and his suggestion that the book needed more "jump" are well known to critics (see Marzorati 78; Tripathi; Rushdie, Joseph Anton 167). As a nod to this primary reader, the author's dedication in Haroun takes the form of an acrostic poem, in which the first letters of the poem's lines spell out Zafar's name. He similarly dedicates Luka and the Fire of Life with an acrostic poem to his second son, Milan.

3. Notably, with the exception of Collins this list is composed entirely of male authors. The lack of diversity and the predominance of male authors in this subgenre is reflected in the gaming industry itself. The recent harassment of female game critics and developers including Anita Sarkeesian and Zoe Quinn is evidence that in spite of high female participation in gaming culture, a violent subculture of sexual discrimination still exists within the industry (Dewey; Collins). See Kafai et al. for an exploration of these issues.

4. This article is a portion of a book chapter in which I discuss Rushdie's and Kostick's work to promote the positive potential for intergenerational cooperation via gaming.

5. By Rushdie's own account in Joseph Anton, he survived at least two assassination attempts, thanks to protection from the British secret service. See also Elst; Puddington.

6. As with much of this novel as well as of Haroun, it is impossible not to read the story of Luka's birth without making connections to Rushdie himself. The author was fifty-seven years old when his son Milan was born (nineteen years after the birth of his brother Zafar) and has spoken frequently about the simultaneously frightening and rejuvenating qualities of being an older parent (Joseph Anton; interviews with Medley, Rustin, and Tripathi).

7. This moment echoes the one in Haroun that similarly sets that novel's plot in motion: Haroun asks his father the accusatory question, "What's the use of stories that aren't even true?" (20; emphasis in original) and inadvertently paralyzes Rashid Khalifa's legendary storytelling capabilities.

8. Nobodaddy is a character who first appears in William Blake's Notebook (written c. 1793) and represents a distant, patriarchal Christian god, "silent and invisible/Father of jealousy” (Blake, “To Nobodaddy” 1.1-2). Rushdie himself has described Blake's work as "the classic meditation on the interpenetration of good and evil" ("In Good Faith"), a description that parallels his own Nobodaddy, who represents the interpenetration of life and death.

9. See The Hero with a Thousand Faces (1949), in which Joseph Campbell argues that the epic quest serves as a vehicle for the hero to attain self-knowledge and, ideally, use this knowledge to make the world better for all people.

10. The plot of Haroun and the Sea of Stories is set in motion when Haroun's mother, Soraya, abruptly abandons her family for an unimaginative accountant. Soraya does not respect Rashid's constant reliance upon imagination and invention, telling him, "You are 
only interested in pleasure, but a proper man would know that life is a serious business. Your brain is full of make-believe, so there is no room in it for facts. Mr. Sengupta has no imagination at all. This is okay by me" (22). Soraya's criticism foregrounds the very dichotomy that Rushdie later deconstructs: the idea that a person must be either purely imaginative or purely logical.

11. For a comprehensive reading of Eliot as a proponent of both high and low culture, one that importantly revises traditional critical assumptions about Eliot as a cultural elitist, see Chinitz.

12. The Aalim are this text's equivalent to Khattam-Shud; like Haroun's nemesis, they attempt to control the master narrative. Aalim is an Islamic term for scholar (Teverson 77); its connotation unsubtly reminds us of Rushdie's resentment of fundamentalists such as the Ayatollah and their monotextual worldviews.

13. An allusion to Plato's allegory of the cave from The Republic. Plato views human ignorance as an entrapping cave and intellectual knowledge as the means of escape; here, the Aalim seek to keep human beings trapped in the cave.

\section{Works Cited}

Bennet, Dashiell. “Look Who's on Al Qaeda’s Most-Wanted List.” The Wire 1 Mar. 2013. 20 May 2015.

Blake, William. "To Nobodaddy." The Complete Poetry and Prose of William Blake. Berkeley: U of California P, 2008. 471.

Block, Jerald. "Lessons from Columbine: Virtual and Real Rage." American Journal of Forensic Psychiatry 28.2 (2007): 5-33.

Bogost, Ian. Persuasive Games: The Expressive Power of Videogames. Cambridge, MA: MIT P, 2007.

Campbell, Joseph. The Hero with a Thousand Faces. 1949. 3rd ed. Novato, CA: New World Library, 2008.

Cassell, Justine, and Henry Jenkins. From Barbie to Mortal Kombat: Gender and Computer Games. Cambridge, MA: MIT P, 2000.

Chinitz, David. T. S. Eliot and the Cultural Divide. Chicago: U of Chicago P, 2003.

Collins, Sean T. "Anita Sarkeesian on GamerGate: 'We Have a Problem and We're Going to Fix This."” Rolling Stone. Rolling Stone, 17 Oct. 2014. 15 Nov. 2014.

Dewey, Caitlin. “The Only Guide to Gamergate You Will Ever Need to Read.” Washington Post 14 Oct. 2014. 15 May 2015.

Doctorow, Cory. Little Brother. New York: Tor, 2008.

Elst, Koenraad. “The Rushdie Rules.” Middle East Quarterly 5.2 (1998): 31-40.

Eliot, T. S. “Tradition and the Individual Talent." 1919. Selected Prose of T. S. Eliot. Ed. Frank Kermode. San Diego: Mariner/Harcourt Brace Jovanovich, 1975. 37-44.

Ensslin, Astrid. Literary Gaming. Cambridge, MA: MIT P, 2014.

Ferguson, C. J., and J. Kilburn. "The Public Health Risks of Media Violence: A MetaAnalytic Review.” Journal of Pediatrics 154.5 (2009): 759-63. 
Gee, James Paul. What Video Games Have to Teach Us About Learning and Literacy. 2nd ed. New York: Palgrave Macmillan, 2007.

Jenkins, Henry. Confronting the Challenges of Participatory Culture. Cambridge, MA: MIT P, 2009. The John D. and Catherine T. MacArthur Foundation Reports on Digital Media and Learning.

—. "Game Design as Narrative Architecture." First Person: New Media as Story, Performance, and Game. Ed. Noah Wardrip-Fruin and Pat Harrigan. Cambridge, MA: MIT P, 2004. 118-30.

Kafai, Yasmin B., Carrie Heeter, Jill Denner, and Jennifer Y. Sun, eds. Beyond Barbie and Mortal Kombat: New Perspectives on Gender and Gaming. Cambridge, MA: MIT P, 2008.

Kahne, Joseph, Ellen Middaugh, and Chris Evans. The Civic Potential of Video Games. Cambridge, MA: MIT P, 2009. The John D. and Catherine T. MacArthur Foundation Reports on Digital Media and Learning.

Kostick, Conor. Epic. New York: Penguin, 2004.

Lynch, Dennis. “Al Qaeda Hit List Names: Charlie Hebdo's Stéphane Charbonnier, Salman Rushdie Among Global Targets." International Business Times 9 Jan. 2015. 20 May 2015.

Marzorati, Gerald. "Rushdie in Hiding: An Interview." New York Times Magazine 4 Nov. 1990: 30-31, 68, 78, 84-85. 20 May 2015.

Mateas, Michael, and Andrew Stern. "Writing Façade: A Case Study in Procedural Authorship." Second Person: Role-Playing and Story in Games and Playable Media. Ed. Pat Harrigan and Noah Wardrip-Fruin. Cambridge, MA: MIT P, 2007. 183-208.

McGonigal, Jane. Reality Is Broken: Why Games Make Us Better and How They Can Change the World. New York: Penguin, 2011.

Medley, Mark. "The Importance of Story: In Luka and the Fire of Life, Salman Rushdie Pays Tribute to Invention.” National Post 19 Nov. 2010. 20 May 2015.

Puddington, Arch. "Freedom of Expression after 'The Cartoon Wars.” Freedom House. 2006. 20 May 2015.

Rushdie, Salman. Haroun and the Sea of Stories. London: Granta, 1990.

_. "In Good Faith.” Newsweek. Newsweek, 12 Feb. 1990. 15 Sep. 2013.

- Joseph Anton: A Memoir. New York: Random House, 2012.

- Luka and the Fire of Life. 2010. New York: Random House, 2011.

_. "Video Games and the Future of Storytelling." Interview by Max Miller. Big Think.12 Nov. 2010. 20 Mar. 2015.

Rustin, Susanna. “Salman's Children.” The Guardian 1 Oct. 2010. 20 May 2015.

Sarkeesian, Anita. “Damsel in Distress (Part I): Tropes vs. Women.” Feminist Frequency. 7 Mar. 2013. Video. 15 May 2015.

Selfe, Cynthia L., Anne F. Mareck, and Josh Gardiner. "Computer Gaming as Literacy.” Gaming Lives in the Twenty-First Century: Literate Connections. Ed. Cynthia L. Selfe and Gail E. Hawisher. New York: Palgrave Macmillan, 2007. 
Sydell, Laura. “At E3, Critics Renew Calls for More Diverse Video Game Characters.” National Public Radio. National Public Radio, 13 June 2014. Online transcript. 20 May, 2015.

Tavinor, Grant. The Art of Videogames. Chichester, UK: Wiley-Blackwell, 2009.

Teverson, Andrew. "Salman Rushdie's Post-Nationalist Fairy Tales: Haroun and the Sea of Stories and Luka and the Fire of Life." Salman Rushdie. Ed. Robert Eaglestone and Martin McQuillan. London: Bloomsbury, 2013. 72-85.

Tripathi, Salil. "Luka and the Fire of Life Author Salman Rushdie Embraces Two Critics, His Sons.” Washington Post 12 Nov. 2010. 20 May 2015.

Zimmerman, Eric. "Narrative, Interactivity, Play and Games: Four Naughty Concepts in Need of Discipline." First Person: New Media as Story, Performance, and Game. Ed. Noah Wardrip-Fruin and Pat Harrigan. Cambridge, MA: MIT P, 2004. 154-64. 